Review

\title{
Pancreatic Islet Cell Transplantation: Graft Stability and Metabolic Outcomes
}

Khawla F. Ali ${ }^{1}$, Betul Hatipoglu ${ }^{2, *}$

1. Department of Medicine, Royal College of Surgeons in Ireland-Medical University of Bahrain, Bahrain; E-Mail: khawlafouad@hotmail.com

2. Endocrinology and Metabolism Institute, Cleveland Clinic, Cleveland, OH, USA; E-mail: hatipob@ccf.org

* Correspondence: Betul Hatipoglu; E-Mail: hatipob@ccf.org

Academic Editor: Yasuhiko Sugawara

OBM Transplantation

2020, volume 4, issue 3

doi:10.21926/obm.transplant.2003115
Received: June 06, 2020

Accepted: July 02, 2020

Published: July 07, 2020

\begin{abstract}
Pancreatic islet transplantation is a rapidly evolving field. It has been increasingly regarded as a promising approach for the correction of dysglycemia associated with type 1 diabetes mellitus (allogenic islet transplantation), or the prevention of surgical diabetes in chronic pancreatitis subjects undergoing total pancreatectomy (autologous islet transplantation). In this review, we discuss the latest literature pertaining to metabolic outcomes of autologous and allogenic islet transplantation, shedding close light on our own latest experience in the autologous islet transplantation setting.
\end{abstract}

\section{Keywords}

Islet transplant; beta cells; autologous transplant; allogenic transplant

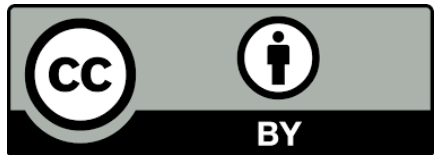

(C) 2020 by the author. This is an open access article distributed under the conditions of the Creative Commons by Attribution License, which permits unrestricted use, distribution, and reproduction in any medium or format, provided the original work is correctly cited. 


\section{Introduction}

Islet transplantation has been increasingly recognized as a viable approach for maintenance and/or restoration of beta cell function. Pancreatic islet transplantation is either performed to correct the dysglycemia associated with type 1 diabetes mellitus [1, 2], or ameliorate surgical diabetes in chronic pancreatitis patients undergoing total-pancreatectomy $[3,4]$. Restitution of endogenous hormonal regulation of glucose levels via transplantation has been shown to significantly improve metabolic outcomes, reduce progression of diabetes-related complications and improve quality of life [5-7]. In this report, we review the current knowledge on pancreatic islet transplantation, shedding light on the durability and metabolic outcomes of autologous and allogenic islet transplantation.

\section{Autologous Islet Transplantation}

Total pancreatectomy (TP) has been increasingly performed for the treatment of chronic pancreatitis (CP) refractory to medical therapy [8-10]. In order to ameliorate the surgical dysglycemia associated with post-pancreatectomy states, the procedure is often coupled with isolation of islets of Langerhans from the resected pancreas, and subsequent infusion of islets back into the host's liver via the portal vein. The surgical procedure, total pancreatectomy and autologous islet transplantation (TPAIT), has been shown to significantly improve pain control, insulin independence rates and overall quality of life in subjects with CP $[7,10]$.

The glycemic outcomes of TPAIT differ across patients. Previous reports at 28-36 months post-TPAIT demonstrated that a third of transplanted patients become normoglycemic and insulin independent, a third show partial islet graft function requiring some exogenous insulin, and a third become fully dependent on insulin therapy $[4,11]$. A critical factor in predicting insulin independence post-TPAIT is the mass of islets transplanted, often expressed as islet equivalent per $\mathrm{kg}$ of bodyweight (IEQ/ $\mathrm{kg}$ ). Subjects receiving $>5000 \mathrm{IE} / \mathrm{kg}$ of bodyweight are at greater odds of achieving insulin independence, whilst those receiving fewer than $2500 \mathrm{IEQ} / \mathrm{kg}$ of body weight are more likely to become insulin dependent post-TPAIT $[4,11,12]$.

However, up to this point, there had been lack of longitudinal data examining the change in engrafted beta cell function over time. In the past year, our group published the first report on the effects of time-lapse on beta cell functionality post-TPAIT [13]. In our analysis, we observed a steady and significant decline in functional beta cell capacity in the first 2 years following transplantation. A steeper decline in graft function was particularly observed in the first 6 months following TPAIT, with the functional decline persisting, but at a slower rate thereafter [13]. The assessment of beta cell functionality in our analysis, as it relates to time, was done via the novel BETA-2 scoring assessment along with the classic mixed-meal tolerance testing. The former tool being a validated refinement of the classic beta-score, a well-established index of islet graft function [14, 15]. The novel BETA-2 score integrates fasting C-peptide, fasting plasma glucose, hemoglobin A1c (HbA1c), and insulin doses to better detect abnormal glucose tolerance and insulin independence following pancreatic islet transplantation. Originally developed and utilized in the allogenic setting, our study was the first to report its applicability in the autologous islet transplantation setting [13]. 
The observed early and persistent decline in islet function has been hypothesized to be due to injury of grafted cells during the transplantation process [16-18]. Harmful events are induced in the early posttransplant period by stressors such as hypoxia, hyperglycemia, and the infiltrating innate immune cellderived cytokines and other pro-inflammatory factors. The isolation procedure itself leads to the devascularization of islets which results in relative underoxygenation, leading eventually to reestablishment of arterialization and adequate oxygenation of intrahepatic islets [19, 20]. Additionally, compelling level of evidence indicts the innate immunity-driven inflammation for the stress and decline in beta cell function in the autologous setting [16-18]. Pro-coagulatory and pro-inflammatory cascades are activated within minutes after islet infusion back into the host and actively contribute to the stress and injury of transplanted islets. The levels of inflammatory cytokines such as IL-1Ra, IL-6, IL-8 and IL10 have been reported to peak within the first 6 hours of islet infusion and gradually subside to pretransplant levels days from islet transplantation [16-18]. To demonstrate this further, we recently analyzed a marker of beta cell stress: the insulin-to-proinsulin index ratio, in subjects pre- and postTPAIT. The latter ratio has been a well-established marker of beta cell stress in the allotransplantation setting [21,22]. The impaired processing of the precursor proinsulin to insulin, and the subsequent lowering of insulin-to-proinsulin index ratio is characteristic of impaired allogenic islet cell function, and has been reportedly present in early allograft failure $[18,21]$. In our autologous islet transplantation analysis, three years post-TPAIT, we observed a significantly lower insulin-to-proinsulin index ratio in insulin-dependent subjects compared to those fully insulin independent [23]. Intriguingly, a significantly lower insulin-to-proinsulin index ratio was also seen in insulin-independent subjects postTPAIT when compared to their pre-TPAIT state [23]. Stemming from the detrimental effects of inflammation peri-transplant on the decline of beta cell mass, rationally-selected anti-inflammatory approaches for patients undergoing TPAIT are increasingly investigated [24, 25]. Such approaches may protect islets from the initial inflammatory challenge; resulting in preservation of beta cell function and leading to sustained long-term insulin independence.

Additionally, for maximization of islet mass infused with concomitant avoidance of increased portal pressure and/or obstruction of portal flow, several groups have looked into alternative, extrahepatic sites for islet transplantation. This approach is further supported by the need to mitigate hypoglycemia associated with intrahepatic infusions. The increased risk of hypoglycemia with exercise and post-meal intervals in subjects with strict intrahepatic infusions of islets has been hypothesized to be due to inhibition of secretion of glucagon by islets surrounded and bathed in the abundant intrahepatic free glucose environment [26]. Additionally, intrahepatic islets are classically exposed to higher concentrations of toxins and/or immunosuppressive agents, all of which can accelerate deterioration of beta cell function. Finally, recent evidence suggests that the latter liver-related factors might be the confounding factor in the relationship between islet mass yield and metabolic outcomes posttransplantation, thereby mandating more research on extra-hepatic sites of transplant [27]. Currently, several centers are utilizing the peritoneal cavity for infusion of excess, remaining islets after liver infusion [28]. Attempts at delivery of the whole islet cell mass in non-hepatic sites, such as the omentum, peritoneal cavity, bone marrow and intramuscular sites are well-underway [29, 30]. 


\section{Allogenic Islet Transplantation}

Islet allotransplantation entails the isolation of islets from donated pancreases of deceased donors without diabetes, and subsequent intrahepatic engraftment in recipients via the portal vein. Islet allotransplantation is reserved for type 1 diabetes mellitus subjects with extreme glycemic variability and/or severe hypoglycemia complicated by hypoglycemia unawareness, or in subjects with functional renal graft. Compared to the more invasive and costly procedure of whole-organ pancreatic transplantation, islet transplantation offers a less aggressive and more affordable route for restoration of beta cell function $[1,2]$.

Metabolic outcomes of allogenic islet transplantation differ across recipients. In its ninth report, the Collaborative Islet Transplant Registry (CITR) published outcomes of 1,011 islet allograft recipients, transplanted between 1999 and 2013 [31]. The registry included 819 allogenic islet transplants alone and 192 islet transplants post-kidney engraftments. The report concluded $50 \%$ of adults with type 1 diabetes achieved insulin independence one-year post-transplantation (alone or post-kidney). Rates of insulin independence, however, declined with time. At 5-years post-transplantation, 30\% of islet transplants alone were insulin independent compared to only $20 \%$ of islets post-kidney [31].

With improvements in procurement procedures, along with the development of less toxic but more effective immunosuppressive agents, the success rates of allogenic islet transplantation have significantly improved. Rates of insulin independence reportedly increased from $27 \%$ to $37 \%$ to $44 \%$ in the eras between 1999-2002, 2003-2006 and 2007-2019, respectively [32]. The need to receive subsequent, additional islet infusions also reduced significantly from $60 \%$ to $65 \%$ to $<50 \%$ in the most recent period [25]. Despite the majority (>90\%) reported to have severe hypoglycemic episodes pretransplant, over $90 \%$ were hypoglycemia-free post-transplant, and up to 5 years of follow up [32]. Additionally, $60 \%$ of subjects were able to achieve near-normal glycemic control (HbA1c <6.5\%) with the first 3-5 years of follow up [32].

Metabolic outcomes of allogenic islet transplantation have also been contrasted against intensification of insulin therapy via continuous insulin infusions, of which the former was found to be superior in several metabolic and glycemic aspects. In the recent multicenter, randomized controlled trial of islet transplantation versus insulin therapy in patients with type 1 diabetes with severe hypoglycemia or poorly controlled glycaemia after kidney transplantation (TRIMECO), islet transplantation was shown to produce significantly lower HbA1c (5.6\% vs $8.2 \%$ ), superior protection from severe hypoglycemia, and significantly improved quality of life compared to intensive insulin therapy, at 6 months post-transplantation [33].

A key factor associated with a higher likelihood of insulin independence post-allogenic islet transplantation is the volume of islets transplanted, as with autologous islet transplantation. In the allogenic setting, this often translates to procurement of islets from multiple deceased donors for maximization of yield. With islets making up less than $2 \%$ of the mass of an adult pancreas, procurement of healthy islets from multiple deceased donors has proven challenging. Attempts at identifying other sources of viable islets has been the subject of many ongoing researches. A major field of interest has been human embryonic stem cells [34-37]. Attempts at differentiating stem cells in vitro to endodermal lines, with further differentiation to glucose-sensing, insulin-producing cells in mice have proven 
successful $[34,36]$. Current efforts are directed at inducing such differentiation to beta-like cells in vitro, for enabling of large volume-production of islets made for human transplantation purposes [37].

Another explored source for islet cell development and production has been xenoislet transplantation. In animal studies, intrahepatically transplanted porcine islets have been shown to maintain normoglycemia in autograft models, suggesting a lesser predisposition to metabolic stress over time [38]. A major drawback of xenoislet transplantation has been the increased risk of hyperacute rejection with porcine immunological triggers, thereby mandating more aggressive immunosuppression regimens [39, 40]. Current novel approaches are targeting the porcine islet genome, possibly creating a resource for porcine islets less immunogenic for human transplantation purposes than the current form [41].

As with autologous transplantation, inflammation escalating at the time of allotransplant has been shown to lower the functional islet cell mass, estimated at a loss of up to $25 \%$ of total islet yield [42]. One of the main toxic cytokines implicated in toxicity of beta cells at time of infusion has been TNF- $\alpha$ [43]. Current approaches adapted incorporate the slow-release pentoxifylline agent, an inhibitor of TNF- $\alpha$ production, to be started 2 days prior to transplant and continued for 7 days post-transplant. Additionally, and immediately prior to operative islet infusion, the TNF- $\alpha$ inhibitors etanercept is intravenously administered, and continued on days 3, 7 and 10 post-transplantation [43].

\section{Conclusions}

Pancreatic islet transplantation is a rapidly evolving field. Efforts are currently focused on improving islet quality and yield, in the autologous and allogenic setting, for improvement of metabolic outcomes and quality of life in the long-run.

\section{Author Contributions}

Dr. Khawla F. Ali and Dr. Betul Hatipoglu both contributed to the drafting and revision of the manuscript.

\section{Funding}

No commercial financial support was received in support of this paper.

\section{Competing Interests}

The authors have nothing to disclose in relation to this manuscript.

\section{References}

1. Robertson RP. Islet transplantation as a treatment for diabetes - a work in progress. N Engl J Med. 2004; 350: 694-705.

2. Rother KI, Harlan DM. Challenges facing islet transplantation for the treatment of type 1 diabetes mellitus. J Clin Invest. 2004; 114: 877-883. 
3. Ali KF, Hatipoglu B. Islet cell autotransplantation update. CellR4 Repair Replace Regen Reprogram. 2019; 7: e2609.

4. Johnston PC, Lin YK, Walsh RM, Bottino R, Stevens TK, Trucco M, et al. Factors associated with islet yield and insulin independence after total pancreatectomy and islet cell autotransplantation in patients with chronic pancreatitis utilizing off-site islet isolation: Cleveland Clinic experience. J Clin Endocrinol Metab. 2015; 100: 1765-1770.

5. Thompson DM, Meloche M, Ao Z, Paty B, Keown P, Shapiro RJ, et al. Reduced progression of diabetic microvascular complications with islet cell transplantation compared with intensive medical therapy. Transplantation. 2011; 91: 373-378.

6. Vantyghem MC, Quintin D, Caiazzo R, Leroy C, Raverdy V, Cassim F, et al. Improvement of electrophysiological neuropathy after islet transplantation for type 1 diabetes: A 5-year prospective study. Diabetes Care. 2014; 37: e141-e142.

7. Walsh RM, Saavedra JA, Lentz G, Guerron AD, Scheman J, Stevens T, et al. Improved quality of life following total pancreatectomy and auto-islet transplantation for chronic pancreatitis. J Gastrointest Surg. 2012; 16: 1469-1477.

8. Kleeff J, Whitcomb DC, Shimosegawa T, Esposito I, Lerch MM, Gress T, et al. Chronic pancreatitis. Nat Rev Dis Primers. 2017; 3: 17060.

9. Kesseli S, Smith K, Gardner T. Total pancreatectomy with islet autologous transplantation: The cure for chronic pancreatitis? Clin Transl Gastroenterol. 2015; 6: e73.

10. Najarian JS, Sutherland DE, Baumgartner DI, Burke BA, Rynasiewicz JJ, Matas AJ, et al. Total or near total pancreatectomy and islet autotransplantation for treatment of chronic pancreatitis. Ann Surg. 1980; 192: 526.

11. Garcea G, Weaver J, Phillips J, Pollard CA, Ilouz SC, M'Balu AW, et al. Total pancreatectomy with and without islet cell transplantation for chronic pancreatitis. Pancreas. 2009; 38: 1-7.

12. Sutherland DE, Radosevich DM, Bellin MD, Hering BJ, Beilman GJ, Dunn TB, et al. Total pancreatectomy and islet autotransplantation for chronic pancreatitis. J Am Coll Surg. 2012; 214 : 409-424.

13. Ali KF, San Martin VT, Walsh RM, Bottino R, Stevens T, Trucco M, et al. Change in functional beta cell capacity with time following autologous islet transplantation. Pancreas. 2019; 48: 656-661.

14. Ryan EA, Paty BW, Senior PA, Lakey JR, Bigam D, Shapiro AJ. $\beta$-Score: An assessment of $\beta$-cell function after islet transplantation. Diabetes Care. 2005; 28: 343-347.

15. Forbes S, Oram RA, Smith A, Lam A, Olateju T, Imes S, et al. Validation of the BETA-2 score: An improved tool to estimate beta cell function after clinical islet transplantation using a single fasting blood sample. Am J Transplant. 2016; 16: 2704-2713.

16. Naziruddin B, Iwahashi S, Kanak MA, Takita M, Itoh T, Levy MF. Evidence for instant bloodmediated inflammatory reaction in clinical autologous islet transplantation. Am J Transplant. 2014; 14: 428-437.

17. Van Der Windt DJ, Marigliano M, He J, Votyakova TV, Echeverri GJ, Ekser B, et al. Early islet damage after direct exposure of pig islets to blood: Has humoral immunity been underestimated? Cell Transplant. 2012; 21: 1791-1802. 
18. Itoh T, Iwahashi S, Kanak MA, Shimoda M, Takita M, Chujo D, et al. Elevation of high-mobility group box 1 after clinical autologous islet transplantation and its inverse correlation with outcomes. Cell Transplant. 2014; 23: 153-165.

19. Yumiba T, Miyata M, Izukura M, Tanaka Y, Dousei T, Yamaguchi T, et al. Islet rest protects against exhaustion of insulin production in transplanted islets. Transplant Proc. 1992; 24: 995-996.

20. Merino JF, Nacher $V$, Raurell M, Biarnes $M$, Soler J, Montanya E. Optimal insulin treatment in syngeneic islet transplantation. Cell Transplant. 2000; 9: 11-18.

21. Fiorina P, Vergani A, Petrelli A, D'Addio F, Monti L, Abdi R, et al. Metabolic and immunological features of the failing islet-transplanted patient. Diabetes Care. 2008; 31: 436-438.

22. Klimek AM, Soukhatcheva G, Thompson DM, Warnock GL, Salehi M, Rilo H, et al. Impaired proinsulin processing is a characteristic of transplanted islets. Am J Transplant. 2009; 9: 2119-2125.

23. Ali KF, San Martin VT, Hatipoğlu B. Beta cell stress in insulin independent subjects following total pancreatectomy and autologous islet transplantation. Turk Klin Immunol Alerji. 2019; 2019: 39-44.

24. Davalli AM, Scaglia L, Zangen DH, Hollister J, Bonner-Weir S, Weir GC. Vulnerability of islets in the immediate posttransplantation period: Dynamic changes in structure and function. Diabetes. 1996; 45: 1161-1167.

25. Bottino R, Balamurugan AN, Bertera S, Pietropaolo M, Trucco M, Piganelli JD. Preservation of human islet cell functional mass by anti-oxidative action of a novel SOD mimic compound. Diabetes. 2002; 51: 2561-2567.

26. Bellin MD, Parazzoli S, Oseid E, Bogachus LD, Schuetz C, Patti ME, et al. Defective glucagon secretion during hypoglycemia after intrahepatic but not nonhepatic islet autotransplantation. Am J Transplant. 2014; 14: 1880-1886.

27. Hering BJ, Clarke WR, Bridges ND, Eggerman TL, Alejandro R, Bellin MD, et al. Phase 3 trial of transplantation of human islets in type 1 diabetes complicated by severe hypoglycemia. Diabetes Care. 2016; 39: 1230-1240.

28. Sutherland DER, Radosevich DM, Bellin MD, Hering BJ, Beilman GJ, Dunn TB, et al. Total pancreatectomy and islet autotransplantation for chronic pancreatitis. J Am Coll Surg. 2012; 214 : 409-424.

29. Christoffersson G, Henriksnas J, Johansson L, Rolny C, Ahlstrom H, Caballero-Corbalan J, et al. Clinical and experimental pancreatic islet transplantation to striated muscle: Establishment of a vascular system similar to that in native islets. Diabetes. 2010; 59: 2569-2578.

30. Maffi P, Balzano G, Ponzoni M, Nano R, Sordi V, Melzi R, et al. Autologous pancreatic islet transplantation in human bone marrow. Diabetes. 2013; 62: 3523-3531.

31. CITR Ninth Annual Report. Rockville: The Emmes Company; 2020. Available from: https://citregistry.org/system/files/9AR_Report.pdf (Accessed on June 6, 2022).

32. Barton FB, Rickels MR, Alejandro R, Hering BJ, Wease S, Naziruddin B, et al. Improvement in outcomes of clinical islet transplantation: 1999-2010. Diabetes Care. 2012; 35: 1436.

33. Lablanche S, Vantyghem MC, Kessler L, Wojtusciszyn A, Borot S, Thivolet C, et al. Islet transplantation versus insulin therapy in patients with type 1 diabetes with severe hypoglycaemia or poorly controlled glycaemia after kidney transplantation (TRIMECO): A multicentre, randomised controlled trial. Lancet Diabetes Endocrinol. 2018; 6: 527-537. 
34. D'Amour KA, Agulnick AD, Eliazer S, Kelly OG, Kroon E, Baetge EE. Efficient differentiation of human embryonic stem cells to definitive endoderm. Nat Biotechnol. 2005; 23: 1534-1541.

35. Guo T, Hebrok M. Stem cells to pancreatic beta-cells: New sources for diabetes cell therapy. Endocr Rev. 2009; 30: 214-227.

36. Kroon E, Martinson LA, Kadoya K, Bang AG, Kelly OG, Eliazer S, et al. Pancreatic endoderm derived from human embryonic stem cells generates glucose-responsive insulin-secreting cells in vivo. Nat Biotechnol. 2008; 26: 443-452.

37. Stainier D. No stem cell is an islet (yet). N Engl J Med. 2006; 354: 521.

38. Emamaullee JA, Merani S, Toso C, Kin T, Al-Saif F, Truong W, et al. Porcine marginal mass islet autografts resist metabolic failure over time and are enhanced by early treatment with liraglutide. Endocrinology. 2009; 150: 2145-2152.

39. Hering BJ, Wijkstrom M, Graham ML, Harstedt M, Aasheim TC, Jie T, et al. Prolonged diabetes reversal after intraportal xenotransplantation of wild-type porcine islets in immunosuppressed nonhuman primates. Nat Med. 2006; 12: 301-303.

40. Cardona K, Korbutt GS, Milas Z, Lyon J, Cano J, Jiang W, et al. Long-term survival of neonatal porcine islets in nonhuman primates by targeting costimulation pathways. Nat Med. 2006; 12: 304-306.

41. Van Der Windt DJ, Bottino R, Casu A, Campanile N, Smetanka C, He J, et al. Long-term controlled normoglycemia in diabetic non-human primates after transplantation with hCD46 transgenic porcine islets. Am J Transplant. 2009; 9: 2716-2726.

42. Eriksson O, Eich T, Sundin A, Tibell A, Tufveson G, Andersson H, et al. Positron emission tomography in clinical islet transplantation. Am J Transplant. 2009; 9: 2816-2824.

43. Rickels MR, Robertson RP. Pancreatic Islet Transplantation in humans: Recent progress and future directions. Endocr Rev. 2019; 40: 631-668.

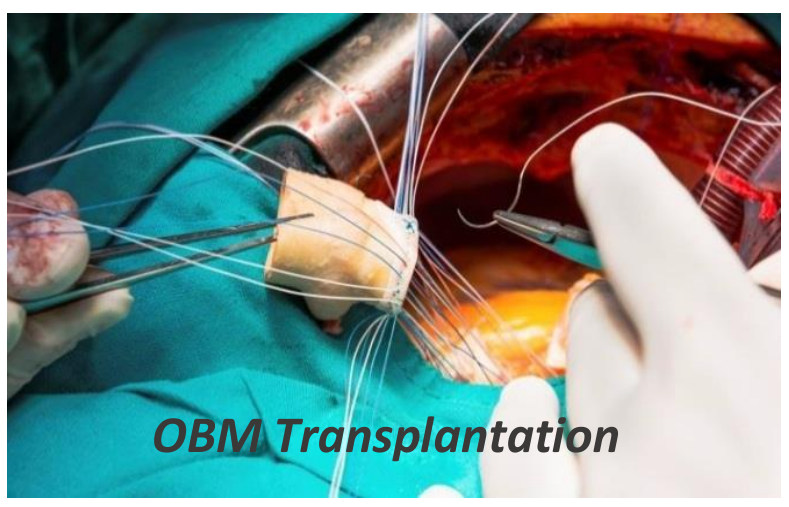

Enjoy OBM Transplantation by:

1. Submitting a manuscript

2. Joining in volunteer reviewer bank

3. Joining Editorial Board

4. Guest editing a special issue

For more details, please visit: http://www.lidsen.com/journals/transplantation 